\title{
The impact of demographic factors on supermarket shopping motivations in South Africa
}

\author{
Eva Nkgome Mahlangu \\ Khathutshelo Mercy Makhitha \\ University of South Africa \\ Department of Marketing and Retail Management, South Africa
}

\begin{abstract}
Keywords
Demographics, shopping motivations, store choice, supermarkets
\end{abstract}

\begin{abstract}
The changing retail environment necessitates a need to manage supermarkets effectively by understanding shopping motivations in order to attract shoppers and remain competitive. The purpose of this research was to determine the factors that motivate shoppers to visit and buy from certain branded supermarkets. In addition, to determine if there is any relationship between shoppers' demographics and shopping motivations. The survey reached 3494 shoppers online of whom 104 responded. The data were analysed using Statistical Package for Social Sciences (SPSS), version 24 for Windows. The findings of the study revealed that shoppers visit specific branded supermarkets for gratification shopping, value shopping, to search for good service and product quality, social shopping and brand hunting. In addition, the findings indicated that gratification shopping and shopping for good service and product quality are significantly affected by gender. Furthermore, the findings revealed there is a significant difference among age groups regarding gratification and social shopping. Moreover, the study found that there is a significant difference among monthly income groups regarding value shopping, social shopping and brand hunting. The findings of this study provide insights for both researchers and retailers to gain a better understanding of supermarket shopping motivations and the relationship between shoppers' demographics and shopping motivations.
\end{abstract}

Corresponding author: Ms Eva Nkgome Mahlangu

Email addresses for the corresponding author: emahlaen@unisa.ac.za

First submission received: 21 $1^{\text {st }}$ May 2018

Revised submission received: $8^{\text {th }}$ August 2018

Accepted: $27^{\text {th }}$ September 2018

\section{Introduction}

The number of supermarkets in South Africa have increased rapidly over the past years. Battersby and Peyton (2014), and Beneke, Hayworth, Hobson and Mia (2012) have identified several factors such as the rise of the middle class, economic expansion and changes in consumer preferences that have contributed to this growth. Das Nair and Chisoro (2015) and the GAIN report (2015) observe that supermarkets have not only grown but the layout and location of supermarkets have also changed. Location is important given that supermarkets have spread from large cities to small cities and eventually to rural areas and villages, targeting traditional, high-end, wealthy shoppers as well as new markets in low-income, rural communities (Battersby et al., 2014). Therefore, location is a motivational factor that shoppers consider when visiting a supermarket. Another motivation for shoppers to visit supermarkets is that they sell a wide range of grocery products at lower prices, therefore providing convenience and monetary value to shoppers. In addition, Van der Heijden and Vink (2013) state that supermarkets also make it convenient for shoppers by extending their offerings to include financial and cellular products and services. Shoppers use supermarkets as a serving point for the payment and purchase of utilities. Quality products and services are store attributes perceived to be motivational factors for choosing a specific store (Chamhuri and Batt, 2013). Supermarkets initially started selling processed food products and non-food products, progressed to selling semi-processed products such as dairy products and then advanced their offerings by selling fresh produce, meat and fish. Supermarkets focus on providing quality products and services, serving as a "one-stop" shop, and an overall customer shopping experience (Das Nair et al., 2015).

www.jbrmr.com A Journal of the Academy of Business and Retail Management (ABRM) 
When shopping, shoppers tend to display economic as well as recreational shopping behaviour. Some shoppers shop to kill boredom, others shop for self-gratification, while others get an emotional fulfilment from shopping (Hasan and Mishra, 2015). It is important for supermarkets to understand what motivates shoppers to visit supermarkets in order to attract these shoppers. While many research papers have been published on supermarkets (Marques, Trindade and Santos, 2016; Malik, 2015; Padhye and Sangvikar, 2016), the focus has been on supermarket attributes. No papers have focused on supermarket shopping motivations in the South African context. Existing research has also focused on shopping motivations towards shopping malls (Jogee and Callaghan, 2014; Kesari and Atulkar, 2016; Bakirtas, Bakirtas and Cetin, 2015). This article will identify the problem statement and objectives, outline the literature review, explain the research methodology and discuss the findings and recommendations.

\section{The problem statement and objectives are outlined in the next section.}

\section{Problem statement and objectives}

While many research papers have been published on supermarkets (Malik, 2015; Marques et al., 2016; Padhye et al., 2016), the focus has been on supermarket attributes. Existing research (Bakirtas et al., 2015; Jogee et al., 2014; Kesari et al., 2016) has focused on shopping motivations at shopping malls. No papers have focused on supermarket shopping motivations in the South African context, thus creating a need to research this. The increasing competition among large retailers compels these retailers to build their competitive advantages in order to survive. This entails understanding what motivates shoppers to shop from a supermarket. Such an understanding enables retailers to formulate an appropriate marketing strategy targeted at shoppers, which in turn determines the size of their share of the market. As supermarkets face competition from local and international players, they must find ways to attract and keep consumers in their stores. Supermarkets must focus on the attributes and shopper motivations that are important to their target market and improve the existing supermarket attributes to attract and keep shoppers (Nguyen, Nguyen and Barrett, 2007). Therefore, this article investigates the shopping motivations of South African shoppers and how demographics influence their shopping motivations.

The following research objectives were formulated for this study:

- To determine the shopping motivations of supermarket shoppers in South Africa.

- To determine if demographic factors influence shopping motivation factors of South African supermarket shoppers.

\section{Literature review}

The literature review conceptualises references relevant to supermarket shopping motivations to critically evaluate the research problem and to achieve the stated research objectives. Understanding shopping motivational factors that are important to shoppers will assist in attracting these shoppers to supermarkets and remaining competitive. Firstly, this section reviews the literature on the South African supermarket industry. Secondly, it highlights factors that motivate shoppers to visit supermarkets.

\subsection{The South African supermarket industry}

Grocery retail is one of the few major growth sectors in South Africa that contribute to financial investments and create new jobs. Formal grocery retailers account for most sales and grocery consumption with approximately $80 \%$ of the grocery retail market (Nortons Inc, 2016). The five major players in the South African supermarket industry are Shoprite and Pick n Pay as market leaders, followed by Spar, Woolworths and Massmart. Shoprite Holdings specialises in food and household items and its market share is estimated at $34 \%$. Pick n Pay Holdings specialises in groceries, clothing and general merchandise and its market share is estimated at 30\%. The Spar Group specialises in foods and general merchandise and holds $26 \%$ market share. Woolworths Holdings specialises in food and clothing and is one of the leading retailers targeting consumers with a higher Living Standards Measurement (LSM). Woolworths' market share is estimated at 8 to 11\% (Das Nair et al., 2015; GAIN report, 2015). It should be noted, however, that there is no consensus on the market share of each supermarket mentioned.

Several other competitors have recently introduced new formats into the industry, including Fruit \& Veg City (including Food Lover's Market), Massmart's Game FoodCo and Cambridge Food, and Choppies, as well as independent supermarket chains, such as the Save Group, which has increased the 
intensity of competition among the grocery retailers in the country (Nortons Inc, 2016). The modern retail industry accounts for approximately $70 \%$ of national retail markets, and within this, supermarkets are an important source of supply in the retail food sector (Standard Bank, 2014). Major retailers in South Africa have also increased their market penetration and marketing efforts through brand promotion and advertising (Durham, 2011), requiring supermarkets to understand shopper motivation to attract shoppers into their stores.

Supermarkets keep evolving by following trends/developments to meet the needs of shoppers. These trends/developments aim to build a broad customer base for different South African demographic profiles by setting up different store formats to meet the needs of shoppers in different income groups (Pereira, 2014). For example, Shoprite Holdings has five different store formats, namely Shoprite, Checkers, CheckersHyper, Usave and OK. Shoprite focuses on the middle to lower market, while Checkers and Checkers Hyper focus on high-end, well-off shoppers. In addition, Usave focuses on economically disadvantaged communities, while OK caters for a wide range of markets, mainly focuses on convenience and is in rural towns and suburbs (Battersby et al., 2014; Das Nair et al., 2015). Therefore, the use of different store formats is a trend in the South African supermarket industry.

In addition, supermarkets collaborating with gas stations is trending in the South African supermarket industry, which is convenient for shoppers (Pereira, 2014, GAIN report, 2015). For example, Pick n Pay Holdings has recently opened Pick n Pay Express franchise stores in collaboration with BP to offer shoppers convenience meals, bakery products, cigarettes, magazines and newspapers (Battersby et al., 2014; Das Nair et al., 2015). Convenience remains popular with shoppers, therefore, there is a demand for longer store hours or even 24-hour shopping (GAIN report, 2015). To extend their convenience offerings, South African supermarkets have introduced value-added offerings such as ATMs (Beneke et al., 2012; Das Nair et al., 2015).

Furthermore, there has been growth in private label products on supermarket shelves. For example, Shoprite has its "Ritebrand", Checkers has its "Housebrand" and Pick n Pay has its "No Name" brand. Private brands are trending and are a way in which supermarkets can differentiate themselves (Das Nair et al., 2015, GAIN report, 2015).

The final trends/developments identified are the use of social media and loyalty programmes. Supermarkets invest extensively in advertising and promotions to attract shoppers and create customer loyalty through the use of loyalty cards. Using social media as a method of advertising may be cheaper and supermarkets are increasingly using such methods (Das Nair et al., 2015, Nortons Inc, 2016).

Although shoppers may shop at supermarkets at the beginning of the month or when there are promotions, some of these shoppers' frequent independent retailers towards month-end. Independent retailers are businesses that are privately owned and do not belong to a larger chain or group. These independent retailers (such as informal spaza shops) are typically small, stock fast-moving items, operate at low profit margins and target shoppers with a lower LSM. With independent retailers becoming more profitable and sustainable, these retailers place supermarkets under competitive pressure; a supermarket may not view an independent retailer as a direct competitor despite both of them offering similar products (Bellini and Cardinali, 2015; Das Nair et al., 2015).

\subsection{Shopping motivations}

In order to draw shoppers to a supermarket, it is necessary to understand what motivates them to visit. Motivation is defined as the process that causes customers to demonstrate a particular behaviour (Cerasoli, Nicklin and Ford, 2014). Extensive research (Bakirtas et al., 2015; Jogee et al., 2014; Kesari et al., 2016) has been conducted on shopping motivations with the focus on shopping malls. Although research has also been done on supermarket shopping motivations, it has not been done in the context of South African supermarkets. Shopping motivations are determined by hedonic and utilitarian shopping motivations. Utilitarian shopping motivation is focused on the functional and objective attributes of visiting retail stores (Bakirtas and Divanoglu, 2013; Cervellon, Sylvie and Ngobo, 2015). Kesari et al. (2016) described utilitarian motivation as task related and dependent on whether the shopper has completed shopping successfully (getting everything done as planned). Utilitarian shopping motivations include achievement and efficiency, which involve shoppers finding items they are looking for within the shortest period, as they had planned (Cardoso and Pinto, 2010). 
On the contrary, hedonic shopping motivation is the joy and pleasure the shopper expects from visiting retail stores, therefore, it is associated with feelings, thoughts and perceptions (Cervellon et al., 2015; Dhurup and Tusiime, 2011; El Hedli, Zourrig and Chebat, 2016; Jayasankaraprasad and Kathyayani, 2014; Kang and Park-Poaps, 2010). Hedonic shopping motivations include gratification, idea, role, value and social shopping. Hedonic shoppers, as observed by Hasan et al. (2015), focus on recreational shopping, for instance, shopping to kill boredom, shopping for self-gratification or shopping to get emotional fulfilment. Gratification shopping involves shopping to relax and relieve stress or when shoppers want to treat themselves to something special (Bakirtas et al., 2013; Cardoso et al., 2010; Cervellon et al., 2015). On the other hand, idea shopping involves shopping to keep up with the latest trends and to see what new products are available. Role shopping involves shopping done for others, for example, shopping for friends and family or even shopping for a perfect gift for someone. Value shopping involves shopping to get the best deal in terms of bargains and special offers (Cardoso et al., 2010). In addition, value shopping may involve shoppers seeking reduced prices on products. Social shopping involves shopping to socialise with others as a bonding experience and to meet up with friends (Cardoso et al., 2010). It is important for supermarkets to understand what motivates shoppers to visit supermarkets in order to attract these shoppers and to contribute to shoppers being loyal. Shopper loyalty refers to the willingness of shoppers to visit the same supermarket for repeat purchases and to recommend the supermarket to others (Nguyen et al., 2007).

Jayasankaraprasad et al. (2014) explored cross-format motivations among grocery shoppers in India. The results identified five shopper motivation segments, namely, economic, convenience, pricepromotional, hedonic and social shoppers. Economic shoppers are value and utilitarian orientated, while convenience shoppers are motivated by local shopping and time saving. Price-promotional shoppers are price-conscious and driven by value for money. Based on these shopping motivations, shoppers patronise more than two store formats for different reasons indicating that no single store format satisfies their diverse needs and wants. Supermarkets have a high percentage of economic and social shoppers. A study done in the United States of America by Yim, Yoo, Sauer and Seo (2014), assessed hedonic shopping motivation effects in utilitarian shopping environments such as supermarkets. The results revealed that the hedonic shopping motivation in a supermarket functions the same way as it does in a shopping mall. In addition, the hedonic shopping motivation induces consumer impulsiveness and encourages shoppers to stay longer in a store.

Baig and Khalid (2016) developed six typologies of shoppers in Pakistan and determined what shopping channels are preferred over others. Leisure shoppers shop to pass time, when they are under stress or when they want to see new products that are available. Variety seeking shoppers visit stores that have a wide variety of merchandise. Social shoppers go shopping with family and friends, seek help when shopping and have discussions with others before making a purchase. Best price seekers always look out for the lowest prices and bargains, while focused shoppers want to shop in the shortest period from the nearest or particular store. Retail assistance seekers view contact with store personnel as important. It was concluded that none of the six typologies is recognised more in shopping at a supermarket, therefore, all typologies identified do shop at supermarkets.

It is evident from previous studies that supermarket shopping motivations have been addressed internationally. Therefore, it is important for the study to determine what motivates shoppers to visit certain branded supermarkets in the South African context.

\subsubsection{Hypothesis development}

Research shows that there is a relationship between shopper demographics and shopping motivations. In a study to determine the key drivers that influence the shopping behaviour of supermarkets in India, Hasan et al. (2015), indicate that shoppers who are below 30 years of age and single, enjoy shopping more as an experience. In addition, shoppers who are 50 years of age or older, indicate that they shop more if they perceive the store image to be better than other stores. Furthermore, shoppers who are between 41 and 50 years of age and unemployed, tend to shop at stores that they perceive to offer better value for money.

Mortimer and Clarke (2011) investigated male supermarket shoppers in Australia. The results indicated five types of shoppers, namely budget-conscious, controlled, egocentric, equitable and 
convenience shoppers. Budget-conscious shoppers are males who are 26 to 45 years old, who are price conscious and always seek value. Controlled shoppers are males under 45 years of age, who enjoy the shopping task and are not sensitive to price. Egocentric shoppers are older males, who purchase unplanned items to treat themselves. Equitable shoppers are younger (18-35 years old), consider products attributes important, compare prices and use catalogues to gain product information. Convenience shoppers, aged between 26 and 36 years, consider store characteristics such as staff, location, trading hours and parking important.

In a study by Kumar (2017) to investigate shoppers' interaction with different retail formats (such as supermarkets and shopping malls) in India, the results disclosed that the main reasons shoppers visit these types of retail formats are to make a specific purchase, for bargain hunting and to browse. More males visited these retail formats with the intention to purchase or browse, while more females had the intentions to hunt for bargains.

Tifferet and Herstein (2012) explored gender differences in brand commitment and hedonic consumption amongst Israel shoppers. The results revealed that women had higher levels of brand commitment and hedonic consumption. For women, shopping is not just about making the right purchase but also about the experience, while men just want to get the job done. Women tend to enjoy shopping more than men.

Studying the differences between female and male shoppers in terms of the pleasure they derive from shopping, Kirgiz (2014) conducted the study in Turkey. The results indicated that female shoppers derive more pleasure from shopping than male shoppers. Female shoppers highlighted that shopping offers a sensation of freedom, buying discounted products is gratifying and it is also perceived as an aspect of socialisation. Therefore, it is found that female shoppers tend to be more "shopaholics" than male shoppers.

Examining how shoppers' demographics influence shopping orientations, Workman and Cho (2012) conducted the study in America. The findings of the study indicated that women and men differ in recreational and convenience shopping orientations but do not differ in quality, brand and price shopping orientations. Women have higher recreational shopping orientations than men and men are more convenience orientated than women. Both men and women are concerned with the price and quality of products and are motivated by brand names of products. The afore-mentioned discussion led to the following hypothesis:

$\mathrm{H}^{1} \quad$ There is a significant difference between the supermarket shoppers' age and shopping motivations.

$\mathrm{H}^{2} \quad$ There is a significant difference between the supermarket shoppers' gender and shopping motivations.

Mehta, Sharma and Swami (2013) investigated segments of Indian hypermarket shoppers based on shopping motivations and profiled these segments according to shoppers' characteristics. According to the results, four segments were identified, namely, utilitarian, maximiser, enthusiast and browser shoppers. Utilitarian shoppers are motivated by functional benefits such as the price and variety of products. Maximiser shoppers seek both functional and recreational benefits. Indian shoppers perceive hypermarkets as a get-away destination for fun. Browser shoppers are motivated by social activities such as watching other people and enjoying the crowd, while enthusiastic shoppers are high on all dimensions of shopping motivation. Browser shoppers are dominated by shoppers who are unmarried. The results further indicated that maximiser shoppers form the largest group of Indian hypermarket shoppers, followed by the browser shoppers.

Examining the influence of retail factors on the age and marital status of women who visit supermarkets, Ramprabha (2018), conducted the study in Puducherry. The findings of the study revealed that marital status has an influence on retail factors such as price/promotions, service and staff. Married shoppers are more influenced towards the retail store factors than the unmarried shoppers.

In a study by Karim, Kumar and Rahman (2013) to examine the differences in shopping values across market segments based on demographics, the study was conducted in Malaysia. The findings of the study disclosed that there are differences in hedonic values across market segments based on age, gender, marital status and income. Shoppers who are married with children have a lower hedonic value 
than unmarried shoppers without children when shopping. However, there are no significant differences in hedonic values amongst shoppers with different income groups. Paulins and Geistfeld (2003) have indicated in their study that shoppers in different income groups perceive store attributes (such as sales assistance) similarly.

In a study to explore shopping motivations, Farrag, El Sayed and Belk (2010) do not concur with findings by Karim et al. (2013) in that browsing/window shopping is more common amongst shoppers with low income. In other studies, by Jayasankaraprasad et al. (2014) and Hasan et al. (2015), the results indicated that there is a relationship between shoppers' income and shopping motivations. Carpenter and Moore (2016) have indicated in their study that shoppers with a higher income expect a higher level of service at supermarkets. The afore-mentioned discussion led to the following hypothesis:

$\mathrm{H}^{3} \quad$ There is a significant difference between the supermarket shoppers' marital status and shopping motivations.

$\mathrm{H}^{4} \quad$ There is a significant difference between the supermarket shoppers' income and shopping motivations.

Therefore, it is critical to determine if the relationship between shopper demographics and shopping motivations also hold true in the South African supermarket context.

\section{Research methodology \\ 4.1. Respondents}

The respondents for this study were adults who are supermarket shoppers. For the purpose of this study, adults are defined as male and female individuals, aged 18 years and older who visit supermarkets. Adult shoppers displayed more experience in terms of being able to answer the proposed questions in the survey. A sampling frame was used as the basis for data collection. This sampling frame of shoppers who purchased at supermarkets was a convenience sample gathered over time by the researchers. This sample frame was used as a database and each individual was invited to take part in an online survey via Survey Monkey. The sample frame consisted of 3494 supermarket shoppers. The study targeted 3494 supermarket shoppers, of whom 104 responded, that is, a response rate of $2.98 \%$. Online surveys have a low response rate, which could be as a result of non-delivery of e-mail (Cooper \& Schindler, 2011).

\subsection{Data collection and measuring instrument}

The questionnaire was developed using the scales of prior research studies (Alhemoud, 2008; Khraim, Khraim, Al-Kaidah and Al-Qurashi, 2011; Larson and Steinhofer, 2005; Mortimer et al., 2011; Moschis, Curasi and Bellenger, 2004; Ness, Gorton and Kuznesof, 2002) to cover shopping motivations considered when visiting a supermarket. Eight demographic questions were included in the questionnaire. In addition, 23 statements of the questionnaire covered shopping motivations considered when visiting a supermarket. Shoppers were expected to rate each of the shopping motivation on a Likert scale from one to five, with one measuring strongly disagree, and five measuring strongly agree. Data were collected online, and shoppers were made aware that completion of the questionnaire was voluntary, and no compensation was made to the shoppers who completed the questionnaire. A total of 3494 questionnaires were distributed and 104 questionnaires were completed, of which all were considered usable.

\subsection{Data analysis}

The data were analysed using Statistical Package for Social Sciences (SPSS), version 24 for Windows. Descriptive statistics were generated, and the results are reported in the next section. Descriptive statistics were used to determine the demographic characteristics of shoppers and supermarket shopping motivations. In addition, factor analysis was conducted to group similar shopping motivations together. In order to investigate the possible effect that demographics have on the shopping motivational factors, ANOVA test was used.

\section{Results and findings}

Demographic profiling of supermarket shoppers 
Table 1 shows the demographics of supermarket shoppers who participated in the study.

\begin{tabular}{|c|c|c|c|c|}
\hline \multicolumn{3}{|l|}{ Demographics } & $\mathbf{N}$ & $\%$ \\
\hline \multirow{3}{*}{ Gender } & \multicolumn{2}{|l|}{ Male } & 51 & $49 \%$ \\
\hline & \multicolumn{2}{|l|}{ Female } & 53 & $51 \%$ \\
\hline & \multicolumn{2}{|l|}{ TOTAL } & 104 & $100 \%$ \\
\hline & \multicolumn{2}{|l|}{$18-24$ years } & 4 & $4 \%$ \\
\hline & \multicolumn{2}{|l|}{$25-29$ years } & 21 & $20 \%$ \\
\hline & \multicolumn{2}{|l|}{$30-39$ years } & 38 & $37 \%$ \\
\hline Age group & \multicolumn{2}{|l|}{$40-49$ years } & 18 & $17 \%$ \\
\hline & \multicolumn{2}{|l|}{$50-59$ years } & 13 & $13 \%$ \\
\hline & \multicolumn{2}{|l|}{$60+$ years } & 10 & $10 \%$ \\
\hline & \multicolumn{2}{|l|}{ TOTAL } & 104 & $100 \%$ \\
\hline \multirow{3}{*}{ Marital status } & \multicolumn{2}{|l|}{ Married } & 58 & $56 \%$ \\
\hline & \multicolumn{2}{|l|}{ Unmarried } & 46 & $44 \%$ \\
\hline & \multicolumn{2}{|l|}{ TOTAL } & 104 & $100 \%$ \\
\hline \multirow{7}{*}{ Monthly income } & $0-R 2500$ & $\$ 0-\$ 179$ & 3 & $3 \%$ \\
\hline & R2501 - R5000 & $\$ 179-\$ 357$ & 8 & $8 \%$ \\
\hline & R5001 - R7500 & $\$ 357-\$ 536$ & 8 & $8 \%$ \\
\hline & R7501 - R12500 & $\$ 536-\$ 893$ & 12 & $12 \%$ \\
\hline & R12501 - R20000 & $\$ 893-\$ 1429$ & 29 & $29 \%$ \\
\hline & Over R20000 & Over \$1429 & 39 & $39 \%$ \\
\hline & \multicolumn{2}{|l|}{ TOTAL } & 99 & $100 \%$ \\
\hline
\end{tabular}

Table 1: Profiling of respondents

Source: Calculated from survey results

Table 1 indicates that males and females were effectively equally represented in the sample, however, the female shoppers were slightly more (51\%) than males. Most shoppers were in the 30 to 39 age group (37\%), married (56\%) and earned a monthly income of more than R12 500 (\$893) (68\%).

Supermarket information

Table 2 indicates the primary supermarket shoppers purchase from, frequency of supermarket visitation and the number of supermarkets shoppers purchase from.

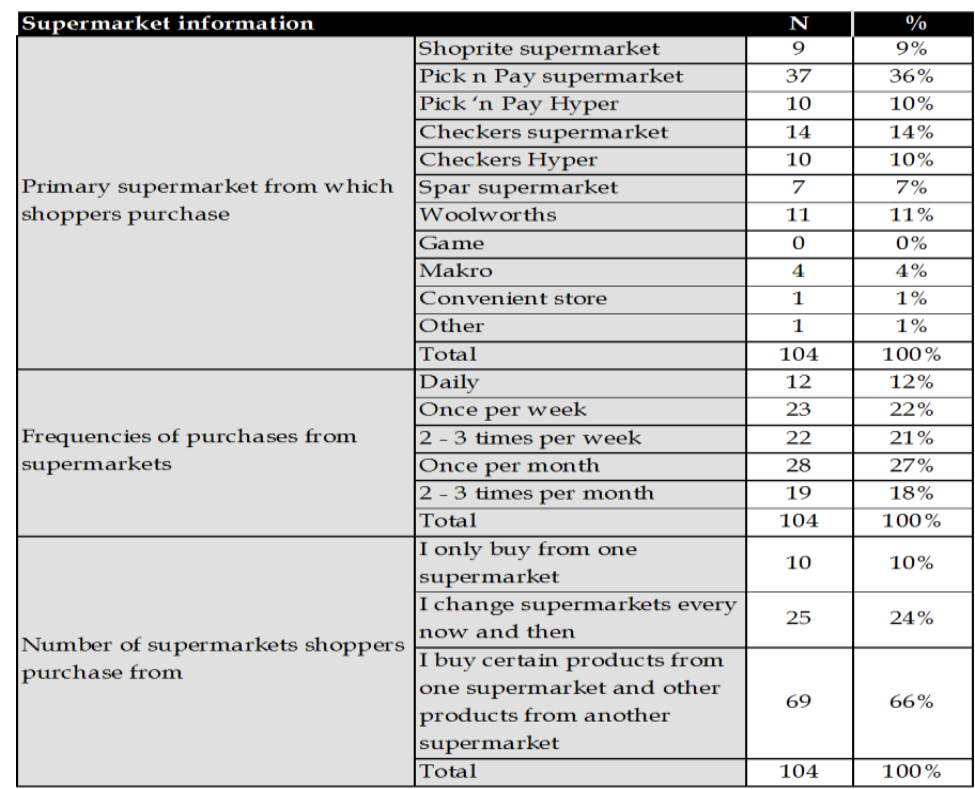

Table 2: Supermarket information

Source: Calculated from survey results

Table 2 shows that supermarket shoppers indicated that Pick $\mathrm{n}$ Pay (36\%) is the most popular supermarket. Furthermore, the shoppers purchased from supermarkets once a month (27\%). Interestingly, shoppers $(66 \%)$ do not stay loyal to one supermarket but buy certain products from one supermarket and other products from another supermarket.

www.jbrmr.com A Journal of the Academy of Business and Retail Management (ABRM) 


\section{Shopping motivations determined by supermarket shoppers in South Africa}

The purpose of the study was to determine what motivates shoppers to visit supermarkets. The statements included in the questionnaire were deemed appropriate (reliable and valid) from previous studies to determine shopping motivations.

Table 3 shows the shopping motivations shoppers consider when visiting a supermarket.

\begin{tabular}{|l|c|c|c|}
\hline Shopping motivations & N & Mean & SD \\
\hline I would like to finish shopping quickly & 103 & 4.20 & 0.833 \\
\hline Service in the store is very important to me & 102 & 4.17 & 0.857 \\
\hline I usually buy from the nearest store & 103 & 3.87 & 0.977 \\
\hline Low price offers attract me & 103 & 3.77 & 0.877 \\
\hline I try to stick to certain brands and stores & 102 & 3.75 & 0.875 \\
\hline I prefer to purchase products that are on sale & 103 & 3.47 & 1.055 \\
\hline I like to try new outlets & 100 & 3.44 & 0.914 \\
\hline $\begin{array}{l}\text { I choose to shop at the grocery store that has the best } \\
\text { deals at the time }\end{array}$ & 101 & 3.44 & 1.062 \\
\hline Large chain stores offer the best value & 102 & 3.41 & 0.989 \\
\hline A well-known brand means good quality & 104 & 3.35 & 1.095 \\
\hline $\begin{array}{l}\text { I am willing to travel far to support a store that meets } \\
\text { my expectations }\end{array}$ & 104 & 3.33 & 1.178 \\
\hline I usually compare prices of different stores & 103 & 3.29 & 1.185 \\
\hline Independent stores provide better service & 103 & 3.19 & 0.805 \\
\hline I prefer to buy national brand-name grocery products & 104 & 3.13 & 1.058 \\
\hline I like to share my shopping experiences with my & 102 & 3.11 & 1.218 \\
\hline I like to have excitement and fun in doing shopping & 104 & 2.94 & 1.164 \\
\hline I feel relaxed after shopping & 104 & 2.85 & 1.18 \\
\hline The price of a product is a good indicator of its quality & 103 & 2.85 & 1.061 \\
\hline I owe it to my community to shop at local stores & 102 & 2.82 & 1.172 \\
\hline $\begin{array}{l}\text { Shopping provides me with social experiences outside } \\
\text { home }\end{array}$ & 102 & 2.82 & 1.277 \\
\hline $\begin{array}{l}\text { I never seem to have enough time to purchase } \\
\text { everything I want to }\end{array}$ & 103 & 2.78 & 1.066 \\
\hline $\begin{array}{l}\text { The more expensive a product the better the quality } \\
\text { I go shopping to make me feel better }\end{array}$ & 103 & 2.74 & 1.163 \\
\hline
\end{tabular}

Table 3: Supermarket shopping motivations

Note $^{*} 1$ = strongly disagree, 5 = strongly agree

Source: Calculated from survey results

The results in Table 3 show that on average, wanting to finish shopping quickly and the importance of in-store service are the most popular shopping motivational factors among supermarket shoppers. The findings of the current study partly agree with the findings of a study by Marques et al. (2016), in that design/layout of the store and staff friendliness were identified as the most important supermarket attributes. The findings of the current study further concur with the study by Bellini et al. (2015) in that shoppers consider the need to save time (easy access of store, store layout and self-service), therefore, for these shoppers, shopping quickly is important. Shopping to feel better is the least important motivation for visiting a supermarket.

\section{Factor analysis}

To reduce the dimensionality of the data, Principal Component Analysis (PCA) using IBM SPSS Statistics 24 was employed to examine patterns of correlations among the questions to measure the level of agreement of the shoppers with statements of possible motivations for doing supermarket shopping.

The factorability of the correlation matrix was investigated using Pearson's product-moment and Spearman correlation coefficients. The correlation matrix demonstrated several coefficients of 0.3 and above. The Kaiser-Meyer-Olkin value was 0.819 , well above the recommended minimum value of 0.6 
(Kaiser, 1970; Kaiser, 1974). Bartlett's Test of Sphericity (Bartlett, 1954) reached statistical significance, $\mathrm{p}<.001$. Thus, the correlation matrix was deemed factorable.

Varimax rotation, a rotation method that endeavours to avoid correlation among the latent factors, was performed. Excluding factor loadings of less than 0.5, resulted in a simple structure (Thurstone, 1947), with each of the five factors showing several strong loadings.

An overall Cronbach's alpha coefficient of 0.89 was achieved with constructs loading a Cronbach alpha of between 0.70 and 0.85 . Malhotra (2010) deems a Cronbach's alpha of 0.60 acceptable and 0.70 to be an indication of satisfactory internal consistency reliability. By allowing all constructs with eigenvalues $\geq 1$, the analysis resulted in a solution with seven latent components/factors. Two of the factors had only two items loading on them. Three items did not load sufficiently on any of the factors and two other items loaded alone on a factor each. These five items were excluded in follow-up runs with the remaining 18 items, resulting in a solution with five latent factors and explaining $70 \%$ of the variance in the data. The factors were named as follows: gratification shopping (factor 1), value shopping (factor 2), good service and product quality (factor 3), social shopping (factor 4 ) and brand hunting (factor 5). The five factors are shown in Table 4.

\begin{tabular}{|c|c|c|c|c|c|}
\hline & $\begin{array}{l}\text { Factor 1: } \\
\text { Gratificatio } \\
\text { n shopping }\end{array}$ & $\begin{array}{l}\text { Factor 2: } \\
\text { Value } \\
\text { shopping }\end{array}$ & $\begin{array}{c}\text { Factor 3: } \\
\text { Good } \\
\text { service and } \\
\text { product } \\
\text { quality }\end{array}$ & $\begin{array}{l}\text { Factor 4: } \\
\text { Social } \\
\text { shopping }\end{array}$ & $\begin{array}{l}\text { Factor 5: } \\
\text { Brand } \\
\text { hunting }\end{array}$ \\
\hline $\begin{array}{l}\text { I like to have excitement and } \\
\text { fun in doing shopping }\end{array}$ & 0.864 & & & & \\
\hline $\begin{array}{l}\text { I go shopping to make me feel } \\
\text { better }\end{array}$ & 0.815 & & & & \\
\hline I feel relaxed after shopping & 0.802 & & & & \\
\hline I like to try new outlets & 0.589 & & & & \\
\hline $\begin{array}{l}\text { I prefer to purchase products } \\
\text { that are on sale }\end{array}$ & & 0.837 & & & \\
\hline Low price offers attract me & & 0.774 & & & \\
\hline $\begin{array}{l}\text { I choose to shop at the } \\
\text { grocery store that has the best } \\
\text { deals at the time }\end{array}$ & & 0.767 & & & \\
\hline $\begin{array}{l}\text { I usually compare prices of } \\
\text { different stores }\end{array}$ & & 0.704 & & & \\
\hline $\begin{array}{l}\text { I never seem to have enough } \\
\text { time to purchase everything I } \\
\text { want to }\end{array}$ & & & 0.795 & & \\
\hline $\begin{array}{l}\text { Independent stores provide } \\
\text { better service }\end{array}$ & & & 0.702 & & \\
\hline $\begin{array}{l}\text { The price of a product is a } \\
\text { good indicator of its quality }\end{array}$ & & & 0.668 & & \\
\hline $\begin{array}{l}\text { The more expensive a } \\
\text { product the better the quality }\end{array}$ & & & 0.631 & & \\
\hline $\begin{array}{l}\text { I like to share my shopping } \\
\text { experiences with my friends }\end{array}$ & & & & 0.755 & \\
\hline $\begin{array}{l}\text { I owe it to my community to } \\
\text { shop at local stores }\end{array}$ & & & & 0.737 & \\
\hline $\begin{array}{l}\text { Shopping provides me with } \\
\text { social experiences outside } \\
\text { home }\end{array}$ & & & & 0.725 & \\
\hline $\begin{array}{l}\text { I try to stick to certain brands } \\
\text { and stores }\end{array}$ & & & & & 0.803 \\
\hline $\begin{array}{l}\text { A well-known brand means } \\
\text { good quality }\end{array}$ & & & & & 0.787 \\
\hline $\begin{array}{l}\text { I prefer to buy national brand } \\
\text { name grocery products }\end{array}$ & & & & & 0.65 \\
\hline Eigenvalues & 6.410 & 2.178 & 1.505 & 1.309 & 1.151 \\
\hline$\%$ of variance $=69.746$ & 35.612 & 12.102 & 8.361 & 7.275 & 6.396 \\
\hline Cronbach alpha & 0.849 & 0.825 & 0.770 & 0.793 & 0.704 \\
\hline Mean score & 2.960 & 3.489 & 2.891 & 2.918 & 3.404 \\
\hline Standard deviation & 0.930 & 0.852 & 0.794 & 1.020 & 0.801 \\
\hline
\end{tabular}

Table 4: Factor analysis - supermarket-shopping motivations

Source: Calculated from Survey results

Table 4 indicates that factor 1 loaded four items, which consisted of items related to shopping for enjoyment and was named gratification shopping. The factor accounted for $35.61 \%$ of the explained variance with an eigenvalue of 6.41 . Factor 2 loaded four items, which consisted of items related to pricing and was named value shopping. Factor 2 accounted for $12.10 \%$ of the explained variance with an eigenvalue of 2.18. According to a study conducted by Mortimer et al. (2011), price, value for money and cleanliness are more important characteristics for female supermarket shoppers in Australia. Factor 2

www.jbrmr.com A Journal of the Academy of Business and Retail Management (ABRM) 
results agree with results by Jayasankaraprasad et al. (2014), in that supermarkets have a high percentage of economic shoppers who are price conscious. In addition, the results concur with those of Kumar (2017), in that the main reason shoppers visit supermarkets is for bargain hunting.

Factor 3 loaded four items, which consisted of items related to products and service and was named good service and product quality. The factor accounted for $8.4 \%$ of the explained variance with an eigenvalue of 1.51. Quality describes the freshness of products available in the store. The perceived freshness of a product and quality of a service influence a shopper's decision to visit a store. The main service encounters in supermarkets are the friendliness of staff and the accuracy and speed of checkout experiences (Beneke et al., 2012; Mortimer et al., 2011; Terblanche and Boshoff, 2004). Malik (2015) investigated the supermarket attributes that consumers prefer while shopping in India. The results revealed that quality and variety of merchandise, store operating hours and convenience of payment facilities were the most important attributes. In another study by Marques et al. (2016), design/layout of the store and staff friendliness were identified as the most important supermarket attributes in Portugal. A study by Bellini et al. (2015) to identify the store motivations considered the most important in Italy, revealed that shoppers consider the need to save time (easy access of store, store layout and self-service), quality of shopping experience (quality of products, environment and customer service), the need to save money and trusting the retailer as important.

Factor 4 loaded three items, which consisted of items related to social activities and accounted for $7.28 \%$ of the explained variance and an eigenvalue of 1.31 . This factor was named social shopping. Factor 4 results do not agree with the results by Jayasankaraprasad et al. (2014) in that supermarkets have a high percentage of social shoppers. Factor 5 loaded three items, which consisted of items related to branding and was named brand hunting. Factor 5 accounted for $6.40 \%$ of the explained variance with an eigenvalue of 1.15 .

Based on the current study factor 2, value shopping (mean score $=3.489$ ) and factor 5 , brand hunting (mean score $=3.404$ ) appear to be the most popular motivations when visiting a supermarket. Factor 1 (mean score $=2.960)$, factor $3($ mean score $=2.891)$ and factor 4 (mean score $=2.918)$ appear to be the least popular motivations when visiting a supermarket.

Impact of demographic factors on shopping motivational factors for supermarket shoppers

The purpose of the study is to determine if there is any relationship between supermarket shoppers' demographics and shopping motivations. Table 5 below shows significant differences between supermarket shoppers' demographics and shopping motivations.

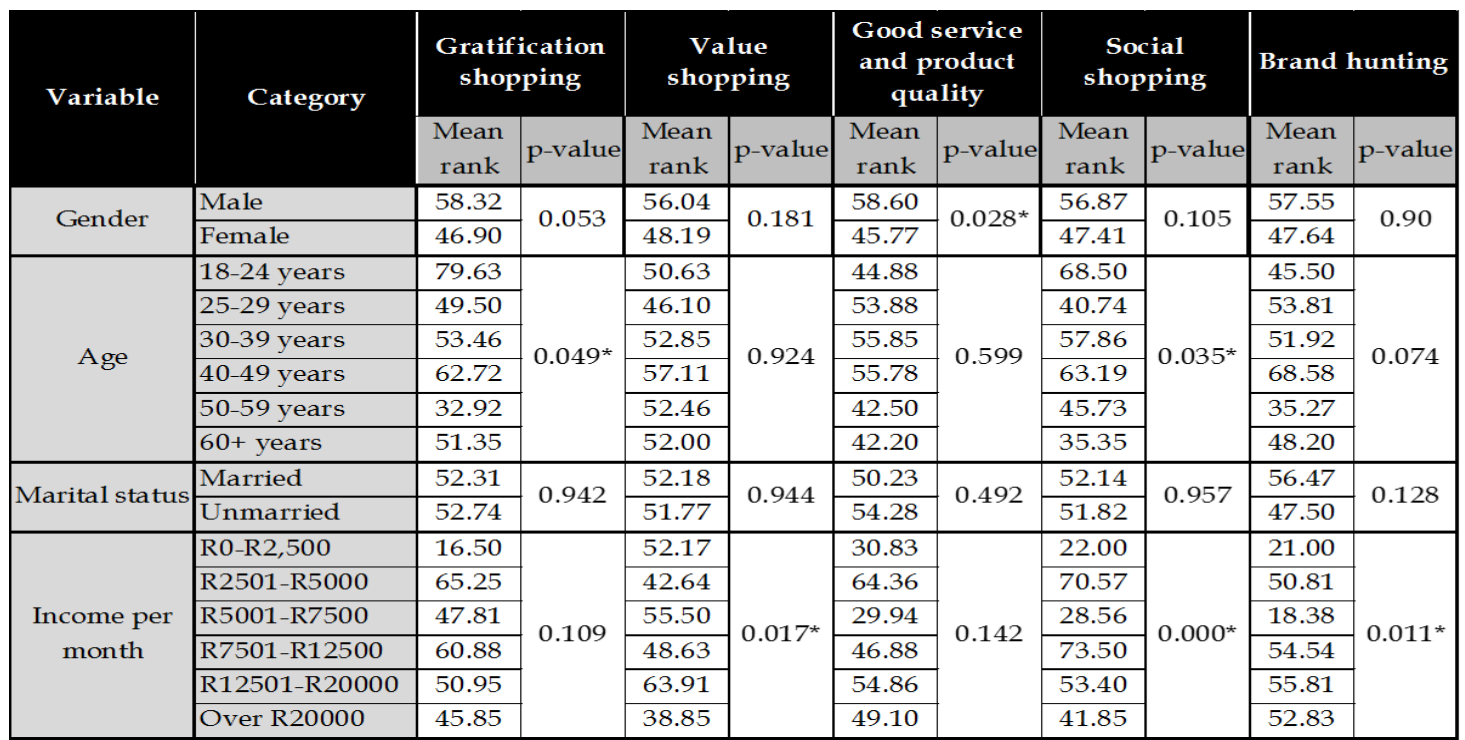

Table 5: Significant differences between groups with respect to shopping motivations

*indicates statistically significant difference between the means of the groups ( $\mathrm{p}$-value less than 0.05) Source: Calculated from survey results 
In Table 5 the impact of demographic factors on shopping motivations are shown. The nonparametric Mann-Whitney $U$ test was used to investigate the possible effect that gender and marital status have on shopping motivational factors. The Mann-Whitney $U$ test indicated that shopping for good service and product quality is a shopping motivational factor significantly affected by gender. Males tend to search for good service and product quality than females. Therefore, these results support $\mathrm{H}^{2}$ in that there is a significant difference between the supermarket shoppers' gender and shopping motivations. These results are not in line with results from a study by Mortimer et al. (2011), in that female supermarket shoppers perceive product quality as more important than male supermarket shoppers.

In addition, the Mann-Whitney $U$ test indicated that marital status does not have a significant effect on any of the shopping motivational factors. Therefore, these results do not support $\mathrm{H}^{3}$ in that there is no significant difference between the supermarket shoppers' marital status and shopping motivations.

In order to investigate the possible effect that age and monthly income have on the shopping motivational factors, the non-parametric Kruskal-Wallis test was used. The Kruskal-Wallis test found that there is a significant difference among age groups regarding gratification shopping and social shopping. Supermarket shoppers who are 18 to 24 years of age tend to shop more for gratification and social purposes. Therefore, these results support $\mathrm{H}^{1}$ in that there is a significant difference between the supermarket shoppers' age and shopping motivations. These results are in line with Karim et al. (2013), in that the hedonic value is higher in younger shoppers (below 35 years) than in older shoppers (above 35 years).

In addition, the Kruskal-Wallis test found that there is a significant difference among monthly income groups regarding value shopping, social shopping and brand hunting. Supermarket shoppers who earn a monthly income of between R12 501 and R20 000 (\$893 and \$1429) are more likely to seek value when shopping and hunt for brands. In addition, shoppers who earn between R7 501 and R12 500 (\$536 and \$893) tend to visit supermarkets to socialise. Therefore, these results support $\mathrm{H}^{4}$ in that there is a significant difference between the supermarket shoppers' income and shopping motivations. Padhye et al. (2016) studied the important store attributes according to customer segments in India. "Apathetic customers" indicated convenient location as the highest attribute, while "casual customers" and "enthralled customers" rated variety of products highest. Enthralled customers are more educated, with a higher income and are below the age of 30 years. Casual customers are employed, highly educated, have a high income and are middle aged. Apathetic customers are young to middle aged, with low income and education degrees.

\section{Recommendations}

In determining the factors that motivate shoppers to visit supermarkets, the findings of the study revealed that shoppers visit supermarkets for value shopping, brand hunting, gratification shopping, social shopping and to search for good service and product quality (shopping motivations ordered from strongest to weakest). In addition, the study revealed that gender, age and income have an impact on these shopping motivations. Therefore, it is important for retailers to segment shoppers in order to tailor their marketing and designing of supermarkets to specific groups.

To capture the attention of supermarket shoppers who visit supermarkets for gratification purposes, it is recommended that retailers should target shoppers, who are 18 to 24 years of age. In addition, retailers should focus on the hedonic features of the supermarket such as the décor and unique products that inspire shoppers' curiosity. Supermarkets can provide gaming and kids' zone for entertainment purposes. Varied experiences may be important for gratification shoppers as they shop for enjoyment (Kim, Lee and Kim, 2011).

In order to attract shoppers who, earn a monthly income of between R12 501 and R20 000 (\$893 and \$1429), supermarkets need to emphasise economic benefits such as price savings in order to attract value shoppers. Offering in-store promotions and discounts may be appealing to these shoppers (Kim et al., 2011). To draw the attention of supermarket shoppers who visit supermarkets for good service and product quality, retailers need to target male shoppers. Retailers need to focus on customer service with friendly and knowledgeable staff trained to assist shoppers (Ertekin, Bayraktaroglu and Gurkaynak, 2014). In addition, supermarket managers can explore the feasibility of services such as home delivery. 
Retailers need to be careful when pricing products as this may be an indicator of the quality of the product.

To capture shoppers who visit supermarkets for social shopping, retailers need to target shoppers who are 18 to 24 years of age and earn between R7 501 and R12 500 (\$536 and \$893). Retailers need to ensure that they invest in space for rest areas and restaurants in store to encourage social interactions among shoppers who visit supermarkets for social purposes (Yim et al., 2014). The inclusion of cafés in supermarkets is evident in Woolworths, where shoppers get to relax and engage with others while having a snack.

It is important for retailers to promote the supermarket as a unique brand for supermarket shoppers who visit supermarkets for brand-hunting purposes. Retailers should target shoppers who earn between R12 501 and R20 000 (\$893 and \$1429) in order to attract these shoppers to supermarkets. In addition, a variety of branded products should be provided in store, giving the shopper options to choose from. Branded products can improve the social status of a shopper in society (Kesari et al., 2016).

It is important for retailers to acknowledge supermarket shopping motivations to attract and retain shoppers. It is also important for retailers to understand that shoppers in different categories react differently to shopping motivations.

\section{Conclusion and limitations}

Although researchers have done research on shopping motivations with the focus on shopping malls, supermarket shopping motivations has not been addressed in the South African context. This study seeks to redress this shortcoming by identifying what motivates shoppers to visit supermarkets, in addition to determining the relationship between shopper demographics and shopping motivations. In conclusion, the findings of the study revealed that shoppers visit supermarkets for gratification shopping, value shopping, to search for good service and product quality, social shopping and brand hunting. In addition, the findings indicated that these shopping motivations are significantly affected by gender, age groups and monthly income groups. The findings of this study provide insights for both researchers and retailers to gain a better understanding of shopping motivations for supermarket shoppers and the impact shoppers' demographics have on these shopping motivations. These insights can assist retailers in better formulating strategies to attract shoppers and remain competitive.

The results of the study should be interpreted in relation to certain limitations. The main limitation for this study was that it focused only on supermarket shoppers who have an online presence as the study was done online. In addition, the study yielded 104 responses out of 3494 supermarket shoppers targeted, which may be considered as a low response rate. Therefore, the findings of this study cannot be generalised to all supermarket stores in South Africa. A sampling frame was used as the basis for data collection, thus, excluding supermarket shoppers outside the sample frame. Future research could focus on other types of retail formats such as departmental stores and investigate the impact of shopping motivations on shopper loyalty, taking into consideration the increase in sample size and eliminating online questionnaires.

\section{References}

Alhemoud, A.M. (2008). Shopping behaviour of supermarket consumers in Kuwait. Journal of Business and Economics Research, 6(3), pp. 47-58.

Baig, F.N. and Khalid, H. (2016). Shopper typology and multi-channel shopping preferences for groceries. The Business and Management Review, 7(3), pp. 34-41.

Bakirtas, H., Bakirtas, I. and Cetin, M.A. (2015). Effects of utilitarian and hedonic shopping value and consumer satisfaction on consumer behavioral intentions. Ege Academic Review, 15(1), pp. 91-98.

Bakirtas, H. and Divanoglu, S.U. (2013). The effect of hedonic shopping motivation on consumer satisfaction and consumer loyalty. International Journal of Asian Social Science, 3(7), pp. 1522-1534.

Bartlett, M.S. (1954). A note on the multiplying factors for various chi square approximations. Journal of the Royal Statistical Society, Series B 16(2), pp. 296-298.

Battersby, J. and Peyton, S. (2014). The geography of supermarkets in Cape Town: supermarket expansion and food access. Urban Forum, 25, pp. 153-164. 
Bellini, S. and Cardinali, M.G. (2015). A consumer perspective on grocery retailers' differentiation. International Business Research, 8(8), pp. 129-140.

Beneke, J., Hayworth, C., Hobson, R. and Mia, Z. (2012). Examining the effect of retail service quality dimensions on customer satisfaction and loyalty: the case of the supermarket shopper. Acta Commercii, 12, pp. 27-43.

Cerasoli, C.P., Nicklin, J.M. and Ford, M.T. (2014). Intrinsic motivation and extrinsic incentives jointly predict performance: a 40-year meta-analysis. Psychological Bulletin, 140(4), pp. 1-29.

Cardoso, P. and Pinto, S. (2010). Hedonic and utilitarian shopping motivations among Portuguese young adult consumers. International Journal of Retail and Distribution Management, 38(7), pp. 538-558.

Carpenter, J.M. and Moore, M. (2006). Consumer demographics, store attributes, and retail format choice in the US grocery market. International Journal of Retail and Distribution Management, 34(6), pp. 434452.

Cervellon, M., Sylvie, J. and Ngobo, P. (2015). Shopping orientations as antecedents to channel choice in the French grocery multichannel landscape. Journal of Retailing and Consumer Services, 27, pp. 31-51.

Chamhuri, N. and Batt, P.J. (2013). Segmentation of Malaysian shoppers by store choice behaviour in their purchase of fresh meat and fresh produce. Journal of Retailing and Consumer Services, 20, pp. 516-528.

Cooper, D.R. and Schindler, P.S. (2011). Business research methods. 11th international ed. New York, NY: McGraw-Hill.

Das Nair, R. and Chisoro, S. (2015). The expansion of regional supermarket chains: changing models of retailing and the implications for local supplier capabilities in South Africa, Botswana, Zambia, and Zimbabwe. United Nations University World Institute for Development Economics Research. WIDER Working Paper 2015/114.

Dhurup, M. and Tusiime, R. (2011). Impulsive buying behavior of apparel merchandise among university students in Southern Gauteng. Journal of Contemporary Management, 8, pp. 517-539.

Durham, L. (2011). Opportunities and challenges for South African retailers. Supermarket and Retailer, pp. 33-35.

El Hedhli, K., Zourrig, H. and Chebat, J-C. (2016). Shopping well-being: is it just a matter of pleasure or doing the task? The role of shopper's gender and self-congruity. Journal of Retailing and Consumer Services, 31, pp. 1-13.

Ertekin, Z.O., Bayraktaroglu, G. and Gurkaynak, N. (2014). Role of shopping motives, age and gender in evaluating retail atmospheric cues. Asian Journal of Marketing, 8(1), pp. 24-43.

Farrag, D.A., El Sayed, I.M. and Belk, R.W. (2010). Mall shopping motives and activities: a multimethod approach. Journal of International Consumer Marketing, 22(2), pp. 95-115.

Gain Report, (2015). South Africa-Republic of retail foods. [Internet:

http:// files.eacce.org.ma/pj/1452234115.pdf, accessed on 2017-07-01].

Hasan, A. and Mishra, S. (2015). Key drivers influencing shopping behavior in retail store. The IUP Journal of Marketing Management, 3, pp. 7-36.

Jayasankaraprasad, C. and Kathyayani, G. (2014). Cross-format shopping motives and shopper typologies for grocery shopping: a multivariate approach. The International Review of Retail, Distribution and Consumer Research, 24(1), pp. 79-115.

Jogee, R. and Callaghan, C.W. (2014). A segmentation of mall shopping motivations in the South African Gauteng provincial context. Mediterranean Journal of Social Science, 5(9), pp. 41-50.

Kaiser, H.F. (1970). A second-generation little jiffy. Psychometrica, 35, pp. 401-415.

Kaiser, H.F. (1974). An index of factorial simplicity. Psychometrica, 39, pp. 31-36.

Kang, J. and Park-Poaps, H. (2010). Hedonic and utilitarian shopping motivations of fashion leadership. Journal of Fashion Marketing and Management, 14(2), pp. 312-328.

Karim, J.A., Kumar, M. and Rahman, S.A. (2013). Measuring shopping values of Malaysian retail consumers. Asia Pacific Journal of Marketing and Logistics, 25(2), pp. 200-224.

Kesari, B. and Atulkar, S. (2016). Satisfaction of mall shoppers: a study on perceived utilitarian and hedonic shopping values. Journal of Retailing and Consumer Services, 31, pp. 22-31. 
Khraim, H.S., Khraim, A.S., Al-Kaidah, F.M., and Al-Qurashi, D. (2011). Jordanian consumer's evaluation of retail store attributes: The Influence of consumer religiosity. International Journal of Marketing Studies, 3(4), pp. 105-116.

Kim, Y-H., Lee, M-Y. and Kim, Y-K. (2011). A new shopper typology: utilitarian and hedonic perspectives. Journal of Global Academy of Marketing Science, 21(2), pp. 102-113.

Kirgiz, A. (2014). Hedonism, a consumer disease of the modern age: gender and hedonic shopping in Turkey. Global Media Journal, 4(8), pp. 200-212.

Kumar, P. (2017). Effect of customers' demographics on retail format choice and interaction: a study on retail sector in India. International Journal of Research - Granthaalayah, 5(1), pp. 316-331.

Larson, R. and Steinhofer, K. (2005). Supermarket selection by singles in the Midwest. Selected paper prepared for presentation at the American Agricultural Economics Association annual meeting, Providence, Rhode Island July 24-27.

Malhotra, N.K. (2010). Marketing research: an applied orientation. 6th global ed. Upper Saddle River, NJ: Pearson.

Malik, N.V. (2015). Store image attributes affecting retail shopping preference: an empirical study. Journal of Advances in Business Management, 1(3), pp. 237-246.

Marques, S.H., Trindade, G. and Santos, M. (2016). The importance of atmospherics in the choice of hypermarkets and supermarkets. The International Review of Retail, Distribution and Consumer Research, 26(1), pp. 17-34.

Mehta, R., Sharma, N.K. and Swami, S. (2013). A typology of Indian hypermarket shoppers based on shopping motivation. International Journal of Retail and Distribution Management, 42(1), pp. 40-55.

Mortimer, G. and Clarke, P. (2011). Australian supermarket consumers and gender differences relating to their perceived importance levels of store characteristics. Journal of Retailing and Consumer Services, 18(6), pp. 575-585.

Moschis, G., Curasi, C. and Bellenger, D. (2004). Patronage motives of mature consumers in the selection of food and grocery stores. Journal of Consumer Marketing, 21(2), pp. 123-133.

Ness, M., Gorton, M. and Kuznesof, S. (2002). The student food shopper: segmentation based on attitudes to store features and shopping behavior. British Food Journal, 104(7), pp. 506-525.

Nguyen, T.T.M., Nguyen, T.D., Barrett, N.J. (2007). Hedonic shopping motivations, supermarket attributes, and shopper loyalty in transitional markets: evidence from Vietnam. Asia Pacific Journal of Marketing and Logistics, 19(3), pp. 227-239.

Nortons Inc. (2016). Grocery retail sector market inquiry index to non-confidential submissions made by Pick $\mathrm{n}$ Pay. [online] Available at: http://www.compcom.co.za/wpcontent/uploads/2016/09/Pick-n-Pay-Submission-Non-Confidential-1.pdf [Accessed 2017-07-01].

Padhye, G and Sangvikar, B.V. (2016). Understanding the repatronage intentions of supermarket customers: a cluster analysis. The IUP Journal of Marketing Management, 2, pp. 46-64.

Paulins, V.A. and Geistfeld, L.V. (2003). The effect of consumer perceptions of store attributes on apparel store preference. Journal of Fashion Marketing and Management: An International Journal, 7(4), pp. 371385.

Pereira, L.M. (2014). The future of South Africa's food system: What is research telling us? SA Food Lab, South Africa. [online] Available at

https://www.researchgate.net/profile/Laura_Pereira4/publication/283714057_The_Future_of_South_Af rica's_Food_System_What_is_research_telling_us/links/56444a3408ae54697fb6b76c/The-Future-ofSouth-Africas-Food-System-What-is-research-telling-us.pdf [Accessed 2017-07-01].

Ramprabha, K. (2018). Assessing the influence of age and marital status of women consumers towards the retail dimensions of the supermarket. International Journal on Global Business Management and Research, 7(2), pp. 39-43.

Standard Bank, (2014). 5-key-trends-affecting-the-retail-market-in-2014. [online] Available at http:/ / bizconnect.standardbank.co.za/sector-news/retail-wholesale/south-africa-5-key-trends-affectingthe-retailmarket-in-2014.aspx [Accessed 2016-07-01]. 
Terblanche, N.S. and Boshoff, C. (2004). The in-store shopping experience: a comparative study of supermarket and clothing store customers. South African Journal of Business Management, 35(4), pp. $1-10$.

Thurstone, L.L. (1947). Multiple factor analysis. Chicago: University of Chicago Press.

Tifferet, S. and Herstein, R. (2012). Gender differences in brand commitment, impulse buying, and hedonic consumption. Journal of Product and Brand Management, 21(3), pp. 176-182.

Van der Heijden, T. and Vink, N. (2013). Good for whom? Supermarkets and small farmers in South Africa: a critical review of current approaches to increasing access to modern markets. Agricultural Economics Association of South Africa, 52(1), pp. 68-86.

Workman, J.E. and Cho, S. (2012). Gender, fashion consumer groups, and shopping orientation. Family and Consumer Sciences Research Journal, 40(3), pp. 267-283.

Yim, MY-C., Yoo, S-C., Sauer, P.L. and Seo, J.H. (2014). Hedonic shopping motivation and co-shopper influence on utilitarian grocery shopping in superstores. Journal of the Academic and Marketing Science, 42 , pp. 528-544. 